
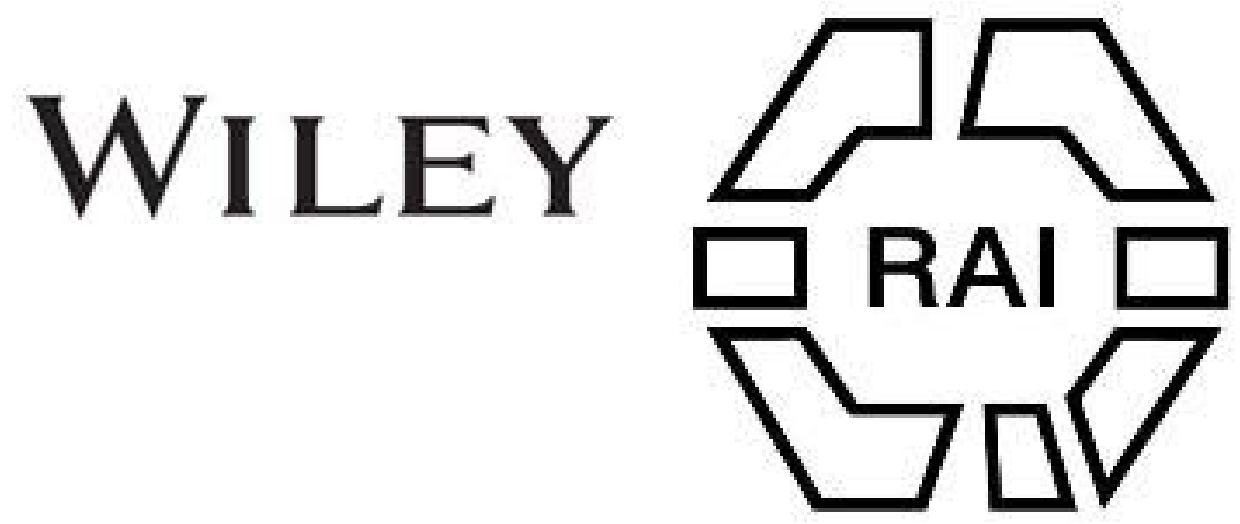

\title{
22. Soudanese Dolls.
}

\section{Author(s): E. A. Gates}

Source: Man, Vol. 3 (1903), pp. 41-42

Published by: Royal Anthropological Institute of Great Britain and Ireland Stable URL: http://www.jstor.org/stable/2839965

Accessed: 27-06-2016 06:19 UTC

Your use of the JSTOR archive indicates your acceptance of the Terms \& Conditions of Use, available at

http://about.jstor.org/terms

JSTOR is a not-for-profit service that helps scholars, researchers, and students discover, use, and build upon a wide range of content in a trusted digital archive. We use information technology and tools to increase productivity and facilitate new forms of scholarship. For more information about JSTOR, please contact support@jstor.org.

Wiley, Royal Anthropological Institute of Great Britain and Ireland are collaborating with JSTOR to digitize, preserve and extend access to Man 
manga. From this idea of a fork or branch has come the other meaning of a fish-hook. Manaia may therefore be made up of the two words mana and $i a$, the Hawaiian word for fish (Maori, ika), so that the translation of manaia is absolutely and literally "fishhook." The full translation, therefore, of Maui's fish-hook is either "fish-hook of Taranga " or else "fish-hook of Raising-up," either of which is appropriate to the hauling up of the islands by Maui. "My impression is," he says, "that munaia is a Maori "word, but that its meauings have come from two different localities-one (Samoan) " 'lizard ' or 'snake,' the other (Hawaiian) ' fish-hook.'" J. EDGE·PARTINGTON.

Egypt.

Gates.

Soudanese Dolls. By $E$. A. Gates; being a Description of Specimens exhibited at a Meeting of the Anthropological Institute, May 13, 1902.

These Soudanese dolls were obtained in Khartoum. Although I have never seen Soudanese children actually playing with such dolls, yet I have no doubt that the dolls were made for their satisfaction and not for the tourists; who, indeed, seldom, if ever, came across any specimen. The only other dolls which I have seen were some in the possession of a British officer at Khartoum, who had got them from the mother of one of his servants. The dolls shown in the photograph were obtained through a Greek merchant at Khartoum. Though made of Nile mud, native gum, and sticks, they are yet in many ways an accurate copy of the women of the country, especially in the matter of their hair and its adornment. The hair is carefully plaited, the number of plaits corresponding to the wealth and social status of the woman, and each plait is fixed by a lump of mud at the end, as the picture clearly shows. The decoration, however, is somewhat more profuse than is usually seen. The clothing, too, is not quite correct. The women, as a rule, wear a long piece of white calico round their bodies over a short apron of strips

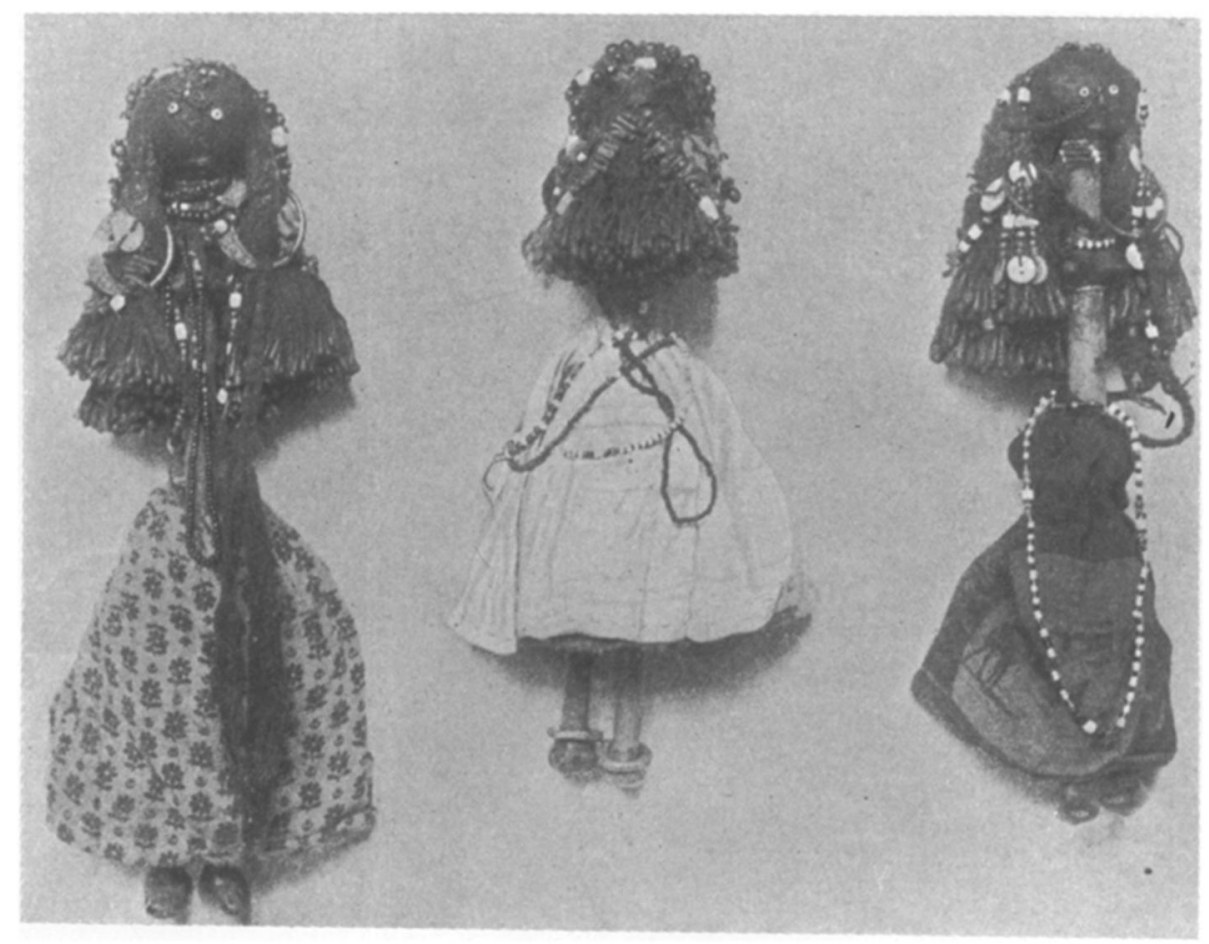

SOUDANESE DOLLS

[ 41 ] 
of leather, and a piece of coloured silk round the lower part of the abdomen. No doubt the dolls' costume owe something to the European women, who, as wives of the Greek merchants, are living in Khartoum and Gmdurman; but the difficulties of adapting the correct clothing to a piece of stick with a lump of mud upon it to represent the hips has something to do with their dress.

E. A. GATES.

\section{REVIEWS.}

India.

Rose. The Punjāb Census. Census of India, 1901, Vols. V., Va., Vb. By H. A. 23
Rose. Simla, 1902. $34 \times 22$. Pp. 140, 387.

The report on the census of 1901 of the Panjāb and the North-West Frontier Province has been written by Mr. H. A. Rose, of the Indian Civil Service, and forms an interesting addition 10 the series of reports on this part of India, which com. mences with Mr. Ibbetson's memorable work in 1883. The newly-formed frontier province, which hitherto formed an integral part of the Panjāb, is still treated jointly with that province, so that a comparison with former results for the whole area dealt with is still possible.

Chapter III. dealing with religion, Chapter VI. with language, and Chapter VIII. with ethnography, are the most interesting parts of the report to anthropologists.

The classification of castes by social precedence, which has been adopted by Mr. Risley in Bengal and in the United Provinces (the North-West Provinces and Oudh of former reports) has not been adopted by Mr. Rose in the Panjāb, and he gives good grounds for holding that any attempt at such classification was doomed to failure (Chap. VIII., 45). It seems very doubtful, indeed, whether such an artificial system can lead to useful results anywhere. Mr. Rose bas arranged the Panjāb castes in four groups, following respectively the types of organisation of the Khatri, the Rajpnt, the Jat, and the Bania. The Brahmans, Aroras, and Bhatias are grouped with the Khatris, the Baloches with the Rajputs, the Gujars with the Jats. The system is a tentative one, and it may be doubted whether it has any advantage orer Mr. Ibbetson's classification by occupation, according to which the landowning and agricultural tribes were placed under one head, the mercantile and professional under another, and vagrants, menials, and artisans under another. Under this arrangement, the mercantile castes, the Bania, Khatri, Arora, Bhatia, and some minor groups, are placed together in what seems the natural and obvious manner, while the Brahmans take their natural place at the head of the professional castes.

No place is apparently found for the Pathans under Mr. Rose's system, and not a single section of the ethnographical chapter is devoted to them. The Baloches are rather awkwardly tacked on to the Rajputs, with whom rhey have little in common. Mr. Rose seems to thiuk that the name Baloch is Indian (Chap. VIII., 29), as he remarks that it is equivalent to Baroch or chieftain. This can only be the Sindhi word Baroch, which is simply the Sindhi pronunciation of Baloch, $l$ becoming $r$ by a weillknown rule in that language. 'The word Baloch was well-known in Persia in the ninth and tenth centuries, long before the Baloches had migrated to the Indian border.

The classification adopted cannot, therefore, be considered altogether satisfactory, and, for purposes of comparison, it would have been more convenient if Mr. Ibbetson's system had been adhered to. It may be noted that anthropometry is not even alluded to, and no attempt is made to arrange the races of the Panjāb by their physical characteristics. It is probable that sufficient material does not at present exist for any such arrangement ; nevertheless, the physical distinctions are realities, and, when it becomes possible, should not be neglecied. It does not by any means follow that any convenient or practical classification of castes must be abandoned, but they should be supplemented by one based on physical facts rather than on modern and artificial conditions. The 